\title{
Environmental Audit and Re-assessment of Some Selected Regionally Important Geological/Geomorphological Sites in Knowsley, UK
}

\author{
Kikelomo Ayeni \\ Dept. of Geography and Environmental Science, Liverpool Hope University \\ Hope Park, Liverpool L16 9JD, United Kingdom \\ E-mail: kikeayeni@yahoo.com \\ Omotayo Ayeni (Corresponding author) \\ Development Management, Land Contamination Unit \\ Epping Forest District Council, Epping, CM16 4BZ, Essex, United Kingdom \\ E-mail: omotayoayeni@yahoo.com
}

Mickey B. Henson

Water Resources Engineering Ltd., Franklin, NC 28734, United States of America E-mail: mbhenson1945@hotmail.com

Tunde Jegede

Geosystems Engineering Ltd., Block 430E, Massana Street, Wuse Zone I

Federal Capital Territory, Abuja, Nigeria

E-mail: jegedeayo49@gmail.com

Received: February 3, 2017 Accepted: February 27, 2017

doi:10.5296/emsd.v6i2.11111 URL: https://doi.org/10.5296/emsd.v6i2.11111

\section{Abstract}

The research involved conducting a site inventory and proposing a management strategy for 
six selected Regionally Important Geological/Geomorphological Sites (RIGSs) namely: Kirkby Brook, Kirkby Brook Waterfall, Knowsley Brook, Knowsley Park, Statd Moers Park and Charlotte's Pagsy. The RIGSs are located in Knowsley Metropolitan Borough Council (MBC), Merseyside County which is North-West of the United Kingdom. The ages of the rock formation in the area range from Carboniferous to Quaternary with respect to geological timescale.

A descriptive research approach was adopted for the study of the RIGSs and data was generated in-situ through geological mapping. This involved direct recording of geological observations in the study area which included site description and assessment, and condition monitoring of the geologically interesting features for a period of four months; October 2012 to January 2013. Photographs were taken to illustrate the site condition at the time the research was conducted. Results showed that the condition at the sites was generally poor and this indicates that a geoconservation management plan is required for the sites suggesting ways of managing and conserving the RIGSs.

This research demonstrates how geo-conservation can inform and enlighten individuals; and how the geological and geomorphological features, processes and sites can contribute to the aesthetics of the environment. It also suggests how it could render socio-economic support for sustainable development to give a strong basis for valuing the abiotic resources and promote the importance of geosciences through the role of sustainable geological key elements and land resources.

Keywords: Environmental audit, Environmental monitoring, RIGSs, Management proposal, Knowsley

\section{Introduction}

Geodiversity is an important component of Britain's natural heritage. Various efforts have been undertaken in the United Kingdom and globally to create awareness and the need to conserve this natural heritage resource. RIGSs, also known as Geodiversity Sites are non-statutory sites which provide important contribution to the overall network necessary to ensure maintenance of the range of diversity of the Earth's Heritage and not only this aspect, but also for education and research, cultural and recreational purposes (Hooke, 2012; Gray, 2013). Knowsley is a metropolitan borough in the county of Merseyside, historic county of Lancashire, England, and it is located at the Eastern flank of Liverpool (UDP, 2003), figure 1.

In this study as it relates to Geodiversity, the management of interesting sites entails the recording and monitoring of local sites which is dependent upon specific aims and objectives (Burek \& Prosser, 2008). In essence, it is required to verify and monitor these areas of importance to gather data which is used to evaluate the resources on site; to develop and implement appropriate geoconservation strategies. RIGSs activity groups exist mainly in the county and the basic duties of the groups involves recognising Geodiversity and recording it. The groups are also charged with the responsibilities of designating sites of importance, conservation and management of geological sites together with creating some information and education platforms. RIGSs groups in the UK operate under the auspices of a national 
body known as UKRIGSs (UKRIGS, 2006). Many RIGSs groups operate through a local organization, such as Wildlife Trust in which services are voluntary, although there may be an officer from a conservation arm of other organisations who undertakes or manages some of the work. RIGSs activities form part of a county's geology group in some counties in the UK (UKRIGS, 2006).

Nature Conservation involves the maintenance of the diversity and vitality of the Earth's wildlife and geology (Royal Society of Nature Conservation, 1999; Webber et al., 2006) and it is expedient to protect important sites and areas with huge influence on the socio-economic fabric of the country and the environment in order to achieve sustainable development. As it is known both locally and internationally, nature conservation is a high priority in Britain and beyond and this area of interest is protected by a wide range national and international legislation. Britain has one of the most varied geosciences in the world and it is acknowledged that science of geology was birthed in the UK (Stewart et al., 2013). Nature Conservation as described by Adams (2003) is a matter of decision about the human actions in the light of their implications for non-human nature and he believes that perhaps, the most critical elements in conservation is the form of human engagement with non-human.

The research carried out by Nature Conservancy Council (NCC, 1990) and Natural England (2008) stipulates that British land is rich in geological and geomorphological features. It reiterates that glacial and periglacial landforms create a window of opportunities to study the Earth's history through rock formation, fossils and minerals. However, this is rapidly disappearing due to some gaps in nature conservation; and also due to negligence in the areas of the Earth's heritage especially in the geological aspect. In spite of these shortcomings in nature conservation (Burek \& Prosser, 2008) acknowledge that recent proactive commitments to the growing awareness of conservation indicate that progress has been made and more efforts will be made to continue to make an important contribution to promote and manage nature in Britain and beyond. In light of the above, Alexander (2008) opined that nature conservation is about enabling the development of the ecosystem.

The Natural England's mandate has to do with the preservation and development of England's natural environment; including its landscapes, biodiversity, geology, soils, natural resources, cultural heritage and other features of the built and natural environment (Natural England, 2011). The reason for conservation of nature is the basic belief that the features are 'worthy of conservation' owing to the special value it possess and this has been in the perspective of sustainability and form a single case study which commenced in the seventeenth century and has been used to establish some parameters through the eighteenth, nineteenth, twentieth and now in the twenty-first century (Tavares et al., 2015).

Policies related to Geodiversity and legislation has been documented historically. The earliest reference in government legislation relevant to Geodiversity and its conservation is the National Trust Act of 1907 which stipulates that the Trust has a statutory duty to promote and enhance the flora, fauna, geology and physiographic features (Gray, 2008). Under the National Parks and Access to the Countryside Act 1949 and other allied legislation, sites can be designated as Sites of Special Scientific Interest (SSSI) or as National Nature Reserve 


\section{Macrothink}

(NNR). Areas of international significance are protected under separate European law and conventions (ODPM, 2006). Other supporting legislative policy framework occurs in the National Parks and Access to Countryside Act of 1949 and the Wildlife and Country Act of 1981 for Sites of Special Scientific Interest (SSSI) and National Nature Reserves (NNR) in which the Natural Environment and Rural Communities Act (2006) established the Natural England from the former English Nature and Countryside Agency. In 2005, the UK Government formally recognised the importance of conserving the Geodiversity in the planning process (ODPM, 2005). Planning Policy Statement 9 (PPS9) sets out planning policies regarding the protection of biodiversity and geological conservation through the planning system in England.

The geology of the Knowsley is dominated by sandstones and mudstones of Triassic age (248-205 Ma) (Natural England, 2011). The Triassic sandstones are of the Sherwood Sandstone group with the sandstones outcropping at the Northern end of the Wirral and Liverpool. Furthermore, the South-Western edge of the Lancashire Coalfield, comprising the Upper Carboniferous Coal Measures (354-290 Ma) outcrops beneath St. Helens and East Liverpool. The majority of the area is mantled by thick deposits of Quaternary age of till and intercalations of sand and gravel deposited by glaciers at the end of the last ice age which is some 15,000 years ago (Natural England, 2011). 


\section{Macrothink}

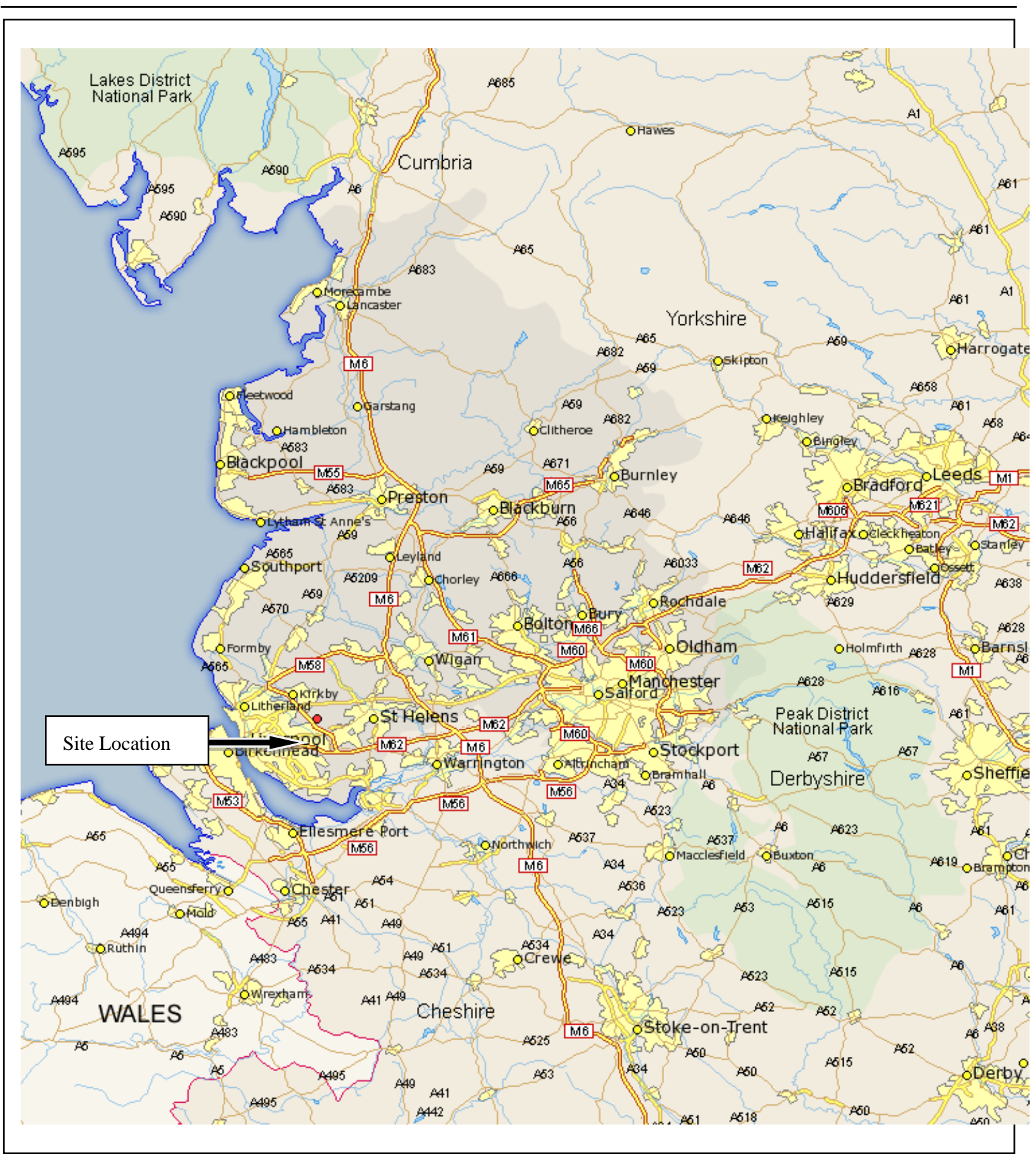

Figure 1. Lancashire Map Showing the location of Knowsley

(Source: Google Maps 2012 retrieved from http://www.itraveluk.co.uk/maps/england/1166/ lancashire/knowsley.html).

In geological conservation, the emphasis is mainly on activities that give rise to conserving the 'features of value' that are under different kinds of threats and to propose a good management action plan to enhance and preserve the geological and geomorphological heritage. This has prompted and inspired various scientists to advocate and get involved in 
making the concept a reality. Some conservationists, such as (Brown, 2012; Whitley et al., 2013; Worton et al., 2013; Wilcox, et al., 2013) in conjunction with individuals, communities, societies, associations, groups, organisations, governments and land-owners have been working tenaciously to make useful contributions to creating innovative solutions and ideas that would enhance the sustainability of geo-conservation. The Geological Conservation Review (GCR) is projected to recognize those sites of national and international significance required to show all the key scientific elements of the Earth heritage of Britain (Walmsley, 2010; Ellis, 2011).

As part of the NCC's mandate to tackle problems facing Geodiversity, an integrated approach to these issues at both international and regional levels is required using an organised statutory and voluntary framework for delivering geo-conservation (Brown et al., 2012; Gray et al., 2013). The authors also indicate that important geological and geomorphological sites and features are conserved through conservation legislation and the development planning system as Sites of Special Scientific Interest (SSSI), whereas locally or regionally important sites are recognised and protected through the planning system as RIGSs.

In Knowsley, most of the sites are designated as both Sites of Biological and Geological Interests (SBI/SGI) and there are more than sixty sites which are locally important and some are identified by the Council as SGI. Hence, for the purpose of this research, six SGI sites are considered including the one that has not been designated yet and under consideration. These sites were identified, assessed and monitored and results are presented accordingly. The research seeks to investigate geoconservation challenges mentioned above and to further conduct environmental audit, assessment and condition monitoring activities in some identified sites in the area.

A review of the six RIGSs in the study area was carried out in order to develop techniques required to solving conservation problems in the field of Geodiversity with reference to Knowsley region. Site audit, evaluation and assessment for management planning are usually a part of the essential components of nature conservation, as it identifies the features of interest that are present for an overall importance. The research is meant to identify areas where there is inadequate management framework for maintaining the aesthetics and integrity of both the biological and geological RIGSs in the study area. The study will also identify the threats to or degradation of the sites and features in question and propose the requirements for identifying values associated with sites of scientific interests. Certain limitations such as restriction of access to some sites due to private ownership and because some other sites are within the industrial area in which access was unauthorised. Also, most of the sites where the brooks are located are covered by vegetation, thereby limiting direct observation of exposed features. Although, these areas are important to the research work but little assessment could be done on the features.

\section{Materials and Methods}

Geological field mapping was carried out in order to map out the areas of interest and assess the features on site. This involved recording data in the field notes and also including the completion of the condition monitoring and the site assessment forms which provided a 
primary source of data for the research work. The approach for the collection of data is based on field investigation for both the geological and biological records. The conventional approach to geological mapping of the sites includes fieldwork, photography, recording in field notes and base maps of geological features on the sites. The biological survey involved recording species that are abundant at the sites for the evaluation of biodiversity data. The basic foundation for conservation, geological/biological audit and mapping has been described (Ellis 2011; Natural England, 2011; Gray et al., 2008).

The investigation conducted on the site was to re-survey the sites, identify both geological and biological features that are of scientific interest and record the data to provide a detailed understanding of the site. Also included is the condition monitoring of the sites which involved setting different goals for management strategy.

\subsection{Geological Field Work}

This involved the collection of data from the RIGSs, identifying the features and geological structures in the study area in order to widen the understanding of the geological history and distribution of the different types of rocks units present in the study area. This mapping technique was adopted to generate a detailed geology of the study area and consolidate the management strategies proposed for conservation purposes.

\subsubsection{Biological Investigation}

Biological investigation was carried out to identify the priority species on the sites and details were recorded in order to achieve some of the objectives of the study which is to maintain processes and interactions in the ecosystem and also form the basis for the management of the sites.

\subsection{Maps}

Ordnance Survey (OS) maps were used as a guide to carry out a detailed survey work in locating the RIGSs region and where there are geologic exposures for the purpose of data collection. The maps used for the investigation was based on 1:1250 and 1:2500 scales.

\subsection{UKRIGS Field Recording and Site Assessment Forms}

The UKRIGS field record site assessment sheet (North Merseyside RIGSs Group) was adopted for the purpose of this research for recording data in the study area. It is a standard form designed by the UKRIGS for this purpose, which provides score values ranging from $0-10$, rating with 0 as the worst and 10 as excellent. The form is divided into two sections, namely; (a) general site information which includes the following: site name and site description, and (b) assessment of value of site which includes the following information: (i) access and safety (ii) education and science (iii) culture, heritage and economics, and (iv) Geodiversity value.

2.3.1 Local Geological Sites/RIGSs Condition Monitoring Form for National Indicator 197 (NI 197) Reporting

The local geological sites/RIGSs condition monitoring form was adopted in this research 
work as developed in partnership with the Malvern Hills AONB, Natural England, Geoconservation UK (formerly UKRIGS), the Geology Trust and Herefordshire and Worcestershire Earth Heritage Trust but has been adapted to North Merseyside RIGSs for the purpose of this research. It highlights the areas of importance to be given much consideration during the monitoring procedure on the sites (UKRIGS). In the form are four sections which comprise of (a) site information: site name and RIGSs ID, site type, date of visit, surveyors name, grid reference, local authority, landowner, British Geological Survey (BGS)/OS sheet number, and RIGSs designation, (b) the primary factors: this section explores the factors that could have direct impact on the different types of exposed features on the site and the scoring system is in form of yes/no answer, (c) the secondary factors: these are factors that do not have direct impact on the exposed features but may need to be managed in order for the features to maintain a desirable condition for their designation; for example, site access, furniture and other factors (d) site status: this includes the present condition of the exposed features at the time of visit to provide information for the purpose of site management and it is recorded/assessed as a yes/no/uncertain answer and the condition status as either good, improving, declining, poor or lost.

\subsection{Photograph (Images)}

One of the key tools in field survey is photography. A digital camera was used during the research work to capture some important images such as the geomorphological features that are exposed.

\section{Results}

This section highlights the results of both the field investigation and previous records from the Merseyside BioBank of RIGSs in Knowsley area. Also included in this section are the RIGSs audit, re-assessment, and condition monitoring report (N197) with the management tools and practices as stated in the methodology section of this work to promote the public understanding of these sites at the local level.

\subsection{Geological Recording of RIGSs in Knowsley}

Data generated from geological field surveys entail records of field observation and interpretation of geological features which includes the nature of rock exposure, structure, features and stratigraphy at each of the site visited. Based on the results, the assessment sheet was based on a landform hierarchy or order (ratings: 1-2 very poor; 3-4 poor; 5-6 acceptable/useful; 7-8 quite good; 9-10 very good/excellent; NA - not applicable; DK - don't know) and this was complemented by descriptive forms and images.

\subsubsection{The Description of the Six RIGSs Surveyed in Knowsley}

This section gives the detailed description of the present RIGSs composition and condition of the surveyed area and this is discussed under the following headings: site name, site number, grid reference, site value (Geodiversity), site threats, site condition, images, and location map showing each of the site and their relationship (figures 2 to 19). More so, this section presents the description of all the surveyed sites as derived from the original RIGSs description when 


\section{Macrothink}

Environmental Management and Sustainable Development

ISSN 2164-7682

2017, Vol. 6, No. 2

visits were made and also from previous information gathered from Merseyside BioBank (MBB).

\subsection{Site Name and Number: Kirkby Brook (L1)}

This site is a little brook located at Kirkby which is accessible to the public. It is an open water course with lithology of sand and gravel. Exposures are of parallel bedding planes with varying lithology along the stream course. Also identified are carbonaceous materials and mud deposits, pebbles and boulders. The lithology is sandstone of Quaternary period (recent) with colour ranging from white to dark-brown. The texture of grain varies in sizes from very fine to coarse and visible mineral constituents are quartz and feldspar group. No visible structural displacement or tectonic activities are evident. Exposed features are covered by plants, trees and algae.

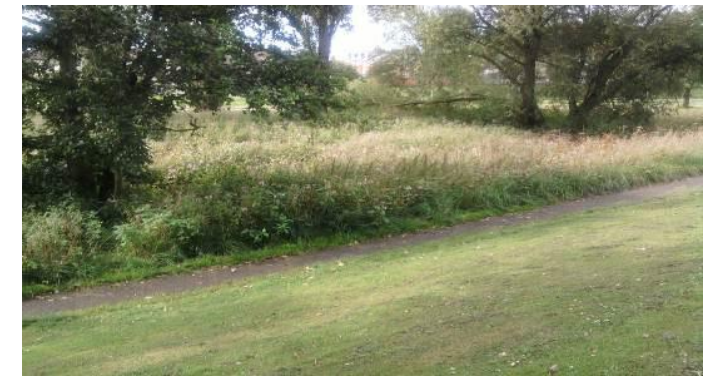

Figure 2. L1a. Brook covered by vegetation (Source: Ayeni et al., 2011)

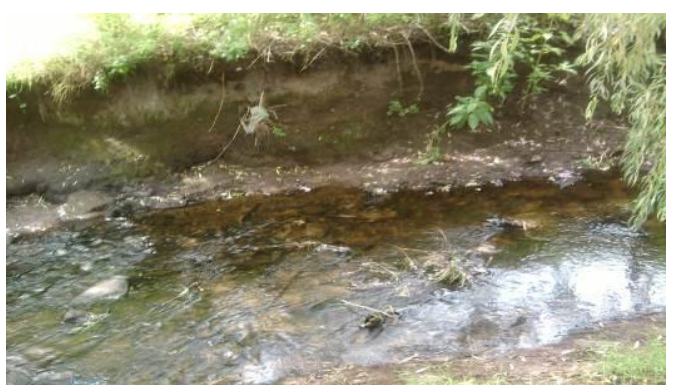

Figure 3. L1b. Observed Lithology at the South of Brook (Source: Ayeni et al., 2011)

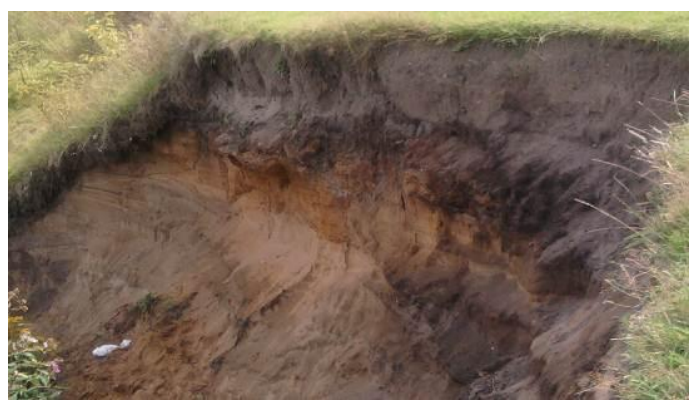

Figure 4. L1c. A massive eroded surface showing the Lithology at the South-end (Source: Ayeni et al., 2011)

\subsection{Site Value (Geodiversity)}

The site is valued for research and educational purposes in relation to the past with the present and it is of high Geodiversity value based on the type of geologic formation that was observed which is of scientific value. It was also observed that the site has a social impact on the local communities which is an added value. It also contributes to the aesthetics of the environment. 


\section{$\triangle$ Macrothink}

\subsubsection{Site Threat}

The site experiences a combination of present and future threats such as huge erosion and weathering of the exposures. Biotic process has a deplorable increase in the amount of vegetation which is obscuring the geological features and therefore the public is not aware of the special features. Although the site environ is well kept with an open field and low grass whereas the site of interest shows no evidence of adequate management. Condition Assessment: Management is required; GOOD.

\subsection{Site Name and Number: Kirkby Brook Waterfall (L2)}

The site is located at Kirkby and to the North of Knowsley. It is about the North end of the Kirkby Brook (L1) and the area is commonly known as Tower Hill. The location is generally a sedimentary terrain with a stream section of active flow and small exposures of geologic features of interest. The observed structure is made up of exposed bedding planes, parallel bedding, and mud clasts with bioturbation. The location is mainly of sandstone and colour ranging from brownish to red and it is of Triassic age. The whole section of the brook is covered by vegetation except some small areas in which the rock exposures are observable.

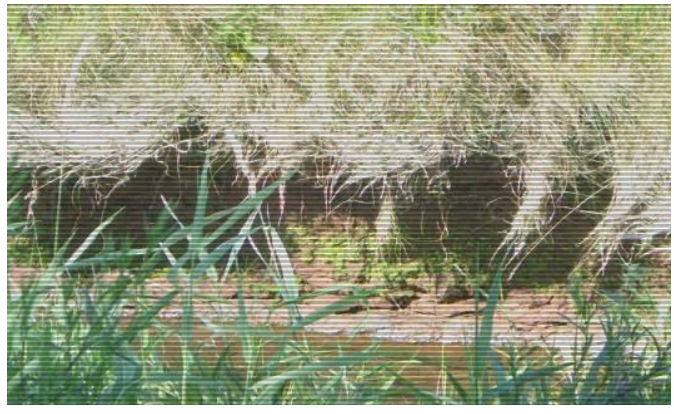

Figure 5. L2b. A small area of good exposure showing the bedding plane (Source: Ayeni et al., 2011).

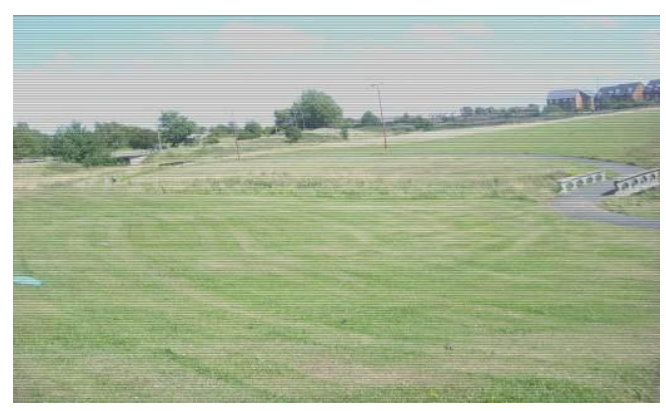

Figure 6. L2c. A general overview of the area (Source: Ayeni et al., 2011)

\subsubsection{Site Value (Geodiversity)}

The area is valued to be a site of appreciation, knowledge and functions and it would contribute to the sustainability of the environment which is one of the key roles in Geodiversity. Therefore, according to previous studies and current analysis, the site is suitable for teaching Earth sciences at the National Curriculum level, advanced level and for projects, adult and continuing education level, at undergraduate level and promote public awareness of Earth Sciences but not sufficient for research work. The site also shows an encouraging modern use, aesthetic value and recreation.

\subsubsection{Site Threats}

The main threat that was observed at the site is the biotic process. For example; overgrown vegetation is increasingly obscuring the exposure and littering of the flowing stream and surrounding field with domestic waste. The area is not affected by recreation rather it beautifies the area and also the cost of management may limit the options for its management 


\section{Macrothink}

plans. Condition Assessment: Management is required; GOOD.

\subsection{Site name and number: Knowsley Brook (L3)}

The site is of sedimentary origin with a stream and sediment deposition along its course. The stream flows from North of the area through a Willow tree plantation to the industrial area where there is limited access. The topography presents high steep sides and covered by vegetation and weeds which obscure the whole exposure and this is an evidence of poor management. The site is composed of sand and sandstone based on the small exposure in some areas with colour ranging from brownish to dark brown. No clear texture was observed but small bedding planes were seen.

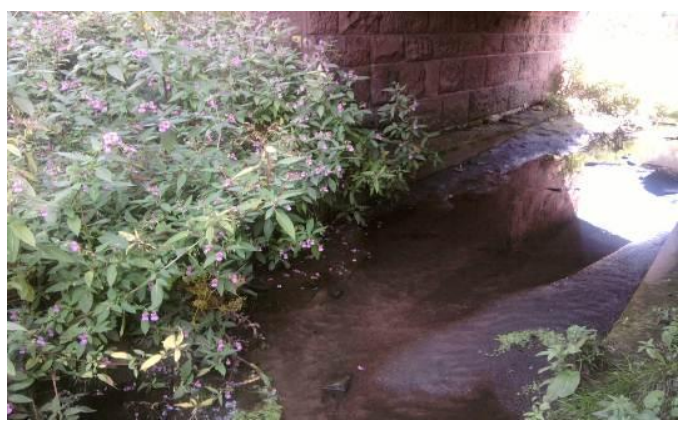

Figure 7. L3a. Section of the site showing recent sand deposition (Source: Ayeni et al., 2011)

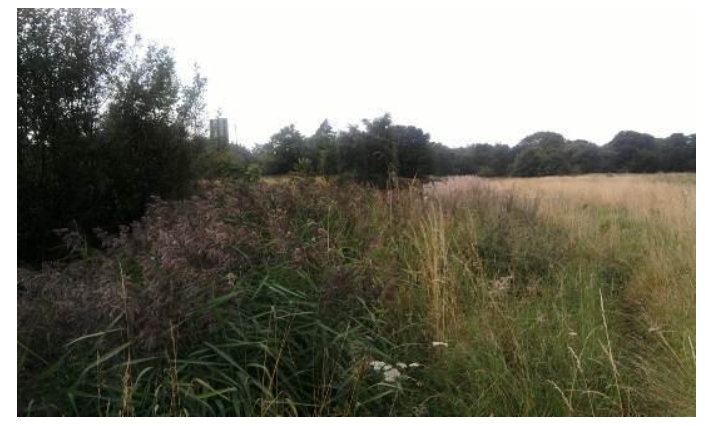

Figure 8. L3b. A long stretch of the site with overgrown vegetation (Source: Ayeni et al., 2011)

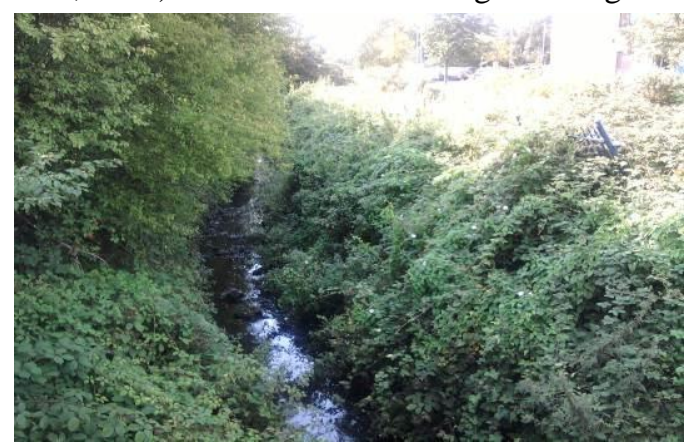

Figure 9. L3c. A section of the site that falls within a privately owned area (Source: Ayeni et al., 2011).

\subsubsection{Site Value (Geodiversity)}

A probable site of Geodiversity value, but geological and geomorphological features could not be seen clearly as a result of fully overgrown vegetation covering the area and also due to limited access. This is due to the industrial and housing activities in the study area and therefore, the area is of limited Geodiversity and educational values. The site can practically be re-exposed by implementing a proper management action plan to attain and maintain a desirable condition for this purpose.

\subsubsection{Site Threats}

Knowsley Brook is seriously being threatened by acute neglect and inadequate management which has made it insignificant in the area. Almost all the sections of the site are covered by 


\section{Mll Macrothink}

Environmental Management and Sustainable Development

ISSN 2164-7682

2017, Vol. 6, No. 2

vegetation which causes it not to be appreciated nor of public interest and most of the section falls within privately owned properties and industrial areas. The cost of management may also limit the options for its future maintenance and sustainability. Condition Assessment: Management required: POOR.

\subsection{Site Name and Number: Knowsley Park (L4)}

This site has exposures of large brownish, fine to medium grains of sandstone ridge with some mafic minerals and it is Quaternary in age. The exposure is partly covered by green lichen, tree roots and vegetation, the surface exhibits some structures; such as, faults with joints and the outcrop displays a tilting large scale of parallel bedding and natural landform is hilly.

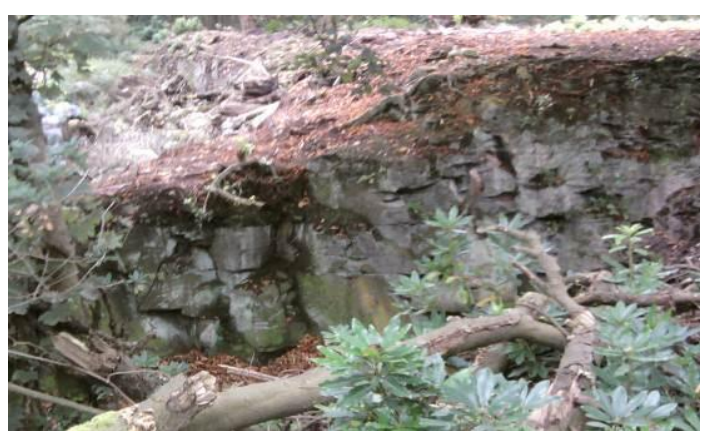

Figure 10. L4a. Rock surface showing parallel bedding covered by lichen (Source: Ayeni et al., 2011)

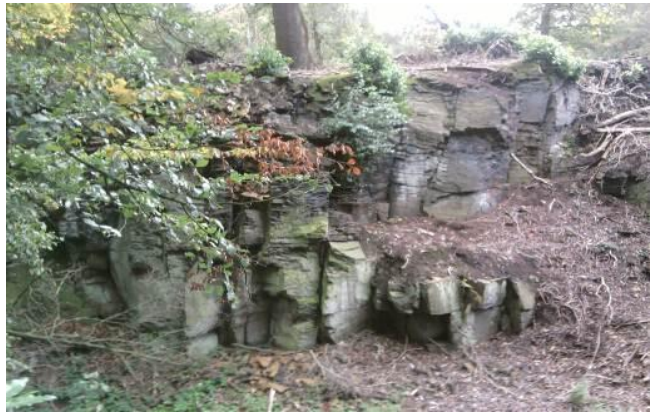

Figure 11. L4b. Exposed surface covered by dead leaves (Source: Ayeni et al, 2011)

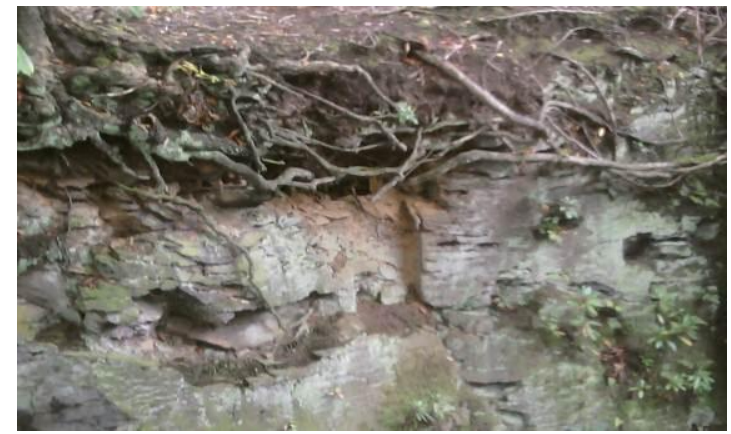

Figure 12. L4c. Weathered surface exhibiting parallel bedding and partly covered by tree roots (Source:

Ayeni et al., 2011)

\subsubsection{Site Value (Geodiversity)}

The site is a park but privately owned, therefore restricted to accessibility. It is useful for educational and research purposes, suitable for teaching Earth Sciences at advanced level and for graduate projects. Public awareness can also be encouraged; therefore the site is of good Geodiversity to study geoconservation or sedimentary processes of sandstone rocks.

\subsubsection{Site Threats}

The site is affected by weathering, encroachment of vegetation and growth of lichen on the surfaces of rock exposure which hinders proper viewing of surfaces. Cost of management 


\section{Macrothink}

may also limit the options for its future management. Condition Assessment: Management is required: GOOD DECLINING.

\subsection{Site Name and Number: Stadt Moers Park (L5)}

The site is a huge landmass which spans Whiston and Huyton. The park is divided into four quadrants and each differs in character and in particular, for the purpose of this research; Quadrant 4 was surveyed which is a large area of biotic nature (grassland and woodland) and consist of mudstone of carboniferous age. The outcrop belongs to the Lower Coal Measure. Sedimentary structure such as concretions was documented.

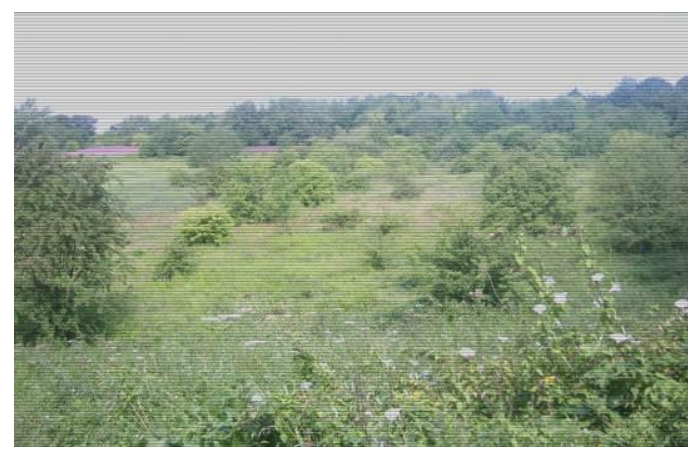

Figure 13. L5a. Site covered with vegetation (Source: Ayeni et al., 2011)

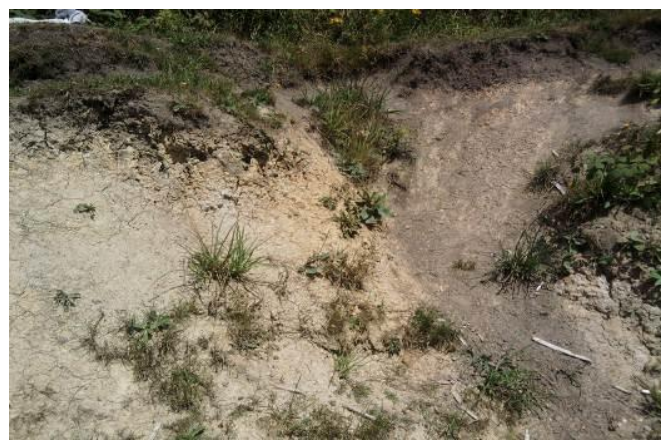

Figure 14. L5b. An area of the exposed rock (mudstone) (Source: Ayeni et al., 2011)

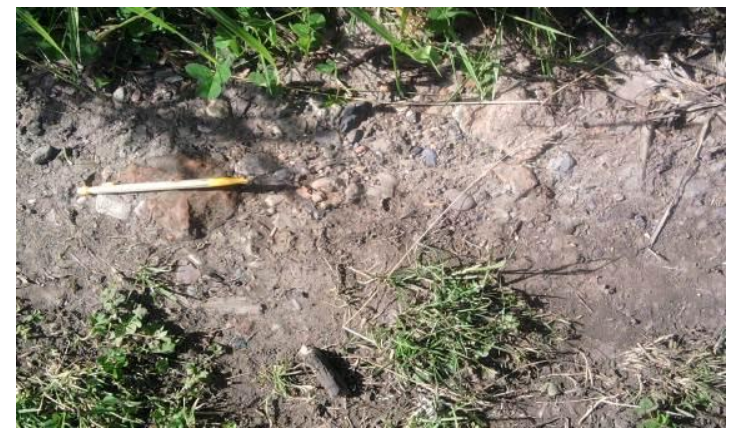

Figure 15. L5c. An area showing buried pebbles

(Source: Ayeni et al., 2011)

\subsubsection{Site Value (Geodiversity)}

Based on history, the area is known to be an area of good culture and heritage which makes it a site of very high value. It has interesting features and good landforms, therefore it is a good area for educational and research purposes and also to promote awareness to the public about the Earth sciences.

\subsubsection{Site Threats}

Areas of rock exposure are gradually being cover up by vegetation and this tends to obscure the features. Also affecting the features are weathering and erosion. Inadequate management 


\section{Ml Macrothink}

Environmental Management and Sustainable Development

ISSN 2164-7682

2017, Vol. 6, No. 2

of the abiotic nature on the site and the cost of management may also limit the options for its future management. Condition Assessment: Management is required: GOOD DECLINING.

\subsection{Site Name and Number: Charlotte's Pagsy (L6)}

The location is a stream floodplain with active streamflow from East to West of the area. The geology is of sedimentary origin which has a lithology of sandstone, probably of the Carboniferous age. Steep rocks surfaces exposed on both sides of the stream along the stream channel; obscured with vegetation, plant roots and trees. The visible and accessible part of the exposure is the other side of the stream which shows the sedimentary structure of distinct parallel bedding plane while it is dark brown in colour.

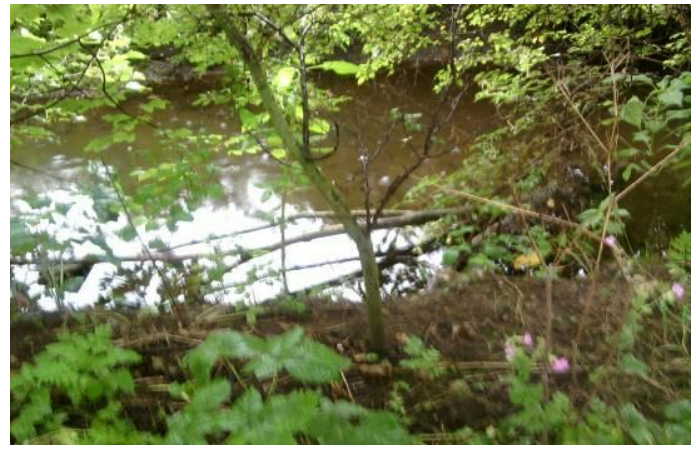

Figure 16. L6a. Section of the stream covered by shrubs and sand deposit along its bank (Source: Ayeni et al., 2011)

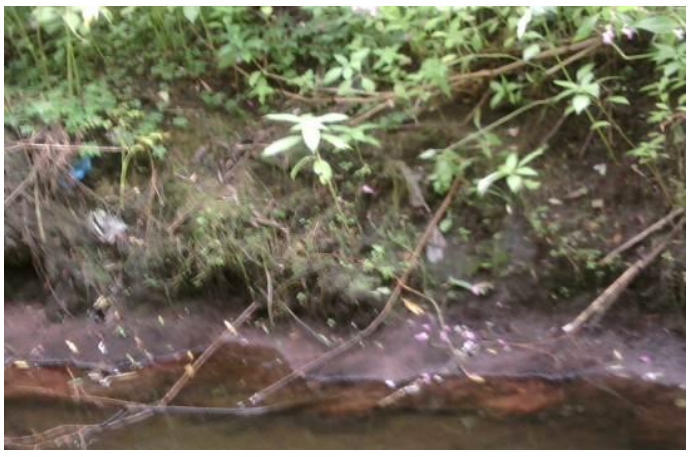

Figure 18. L6c. Section of the exposure feature showing the lithology (Source: Ayeni et al., 2011)

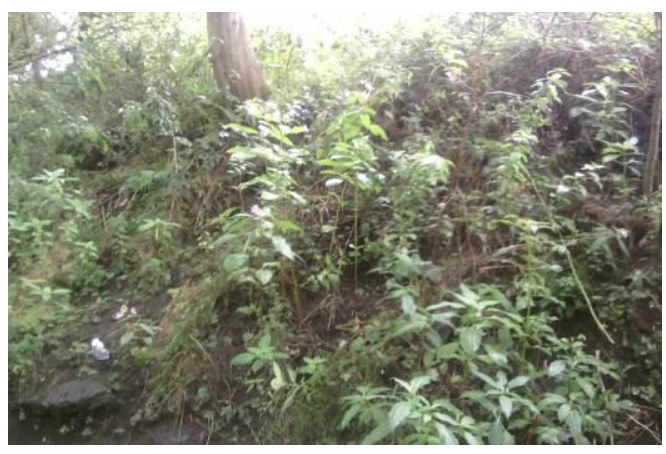

Figure 17. L6b. Stream banks covered by vegetation (Source:Ayeni et al., 2011)

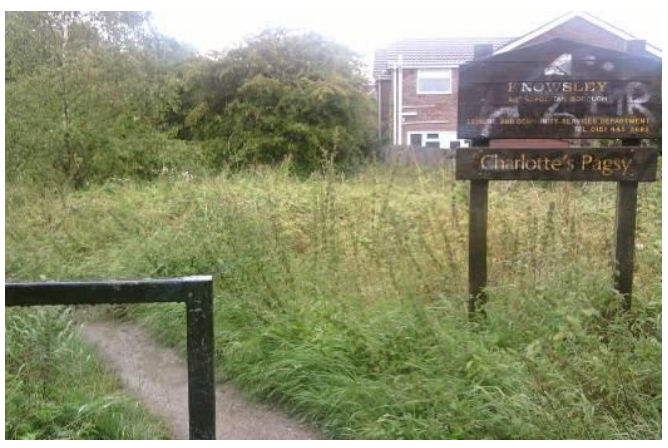

Figure 19. L6d. Accessible footpath covered by vegetation (Source: Ayeni et al., 2011).

\subsubsection{Site Value (Geodiversity)}

The stream section surveyed is yet to be designated but it possesses good geological features and structures which could make it qualify as an important site for nature conservation. The site has great potential because of the existence of an underlying outcrop comprising of consolidated rocks in the area which can be used for educational and scientific purposes and also for the re-construction of the environment. 


\subsubsection{Site Threats}

This site is threatened by vegetation encroachment which obscures the area from the public and might conceal the exposure totally in the near future which might result to abandonment. Dumping of waste in the stream is also a great threat to the area and the cost of management may limit the options for its future management. Condition Assessment: Management is required: POOR DECLINING.

\section{Discussion}

Records from each site surveyed in Knowsley indicates how Geodiversity value has been affected by different impact of both human and natural activities and this represent value and traditions for the protection of geological sites in the area which must be effectively comprehended and necessary action should be taken to revive the degrading situation.

Geological data obtained would be useful in promoting scientific interest of the sites, Geodiversity awareness and enhancement of good practice within the UK and beyond. The audit, re-assessment and condition monitoring of the sites will be useful in updating the previous records in the data bank and to design a holistic approach regarding how the site could be managed, developed, support and promote active geological conservation of RIGSs in Knowsley. As illustrated by Burek and Prosser (2008) that the processes would assist in meeting the demand of rapidly diminishing geological sites and create awareness to geoconservation management practice towards the restoration and maintenance of geological sites. Nature conservation should have a strong position in this process in order to develop a sustainable management. Therefore, the need to integrate economic and environmental decision-making for these sites is crucial.

There has been some criticism against Geodiversity. Some individuals and groups believe that the nature of biodiversity and Geodiversity are not similar, but this has been resolved to a great extent in recent times and with various contributions in the published work that there are important similarities and link between biodiversity and Geodiversity and with such convincing concept; there has been a tremendous progress in geoconservation (Burek \& Prosser, 2008).

\subsection{Conservation Management}

Conservation management has been mapped out from the inception of the NCC and NCR which is used to set the framework for the coordinated management and development of strategy that are most essential for a desired conservation. The management of these RIGSs call for intervention from both statutory and non-statutory institutions to conserve the geologically interesting features to produce a better understanding of the significance, value and need for diverse features observed in the study and thereby enabling more effective strategic planning and management to ensure its preservation and sustainability for the future.

Alexander (2008) and Natural England (2011) opined that for sustainable practice, increased recognition of conservation of the abiotic is very crucial and this has given rise to encouraging the incorporation of nature conservation and management of sites and 
landscapes, which recognizes the need between biodiversity and Geodiversity. Furthermore, organisations are encouraged to establish a holistic approach to design conservation management strategies.

The six RIGSs visited and assessed for this study are examples of exposures that are best conserved for the elements they possess but it is rather unfortunate that they are all in a neglected state and are not adequately managed. RIGSs are meant to be managed properly and implement a suitable management plan for the area which requires physical intervention at the site, either directly or by supervising bodies (Stewart, 2013). More so, by putting into consideration the period the management action would be effected and as well as the resources needed, for example, the cost of management. Presently in the UK, the development of conservation management principles for different site types and condition monitoring are presently in form of statutory requirements (Gordon, 2005) and this is the major key point for this research to develop a geological management strategy for the sites been investigated in Knowsley.

\subsection{Management and Maintenance Strategies for Geological Sites of Integrity}

In describing approaches to site conservation, two contrasting types of sites can be distinguished but they are not mutually exclusive; but each requires a broadly different approach. They are: the 'Exposure' and 'Integrity' sites. The exposure sites are those whose scientific or educational values revolve around providing exposures of geological deposits which are extensive, for example; quarries, rock cuttings and mines.

The integrity sites are those whose value depend on the fact that they contain finite geological deposits or landforms, for example; glacial, fluvial and other associated deposits. In this case, the site survey can be categorised under both the exposure and integrity site group (NCC, 1990). In essence, the management strategy for Geodiversity of these areas involves the safeguarding the geological sites and premium is placed on this approach in favour of preservation and restricting human impacts. Hence, a variety of management actions is essential to be carried out at the early stage of declaration process, which includes the production of management proposal, assessment of management guidelines and methods designed for the maintenance of the RIGSs.

\subsection{Production of Site Management Plan}

The responsibility for the maintenance of these RIGSs is the production of a site management plan and this requires the understanding of the condition of the sites' natural and cultural features. Alexander (2008) proposed that management strategy is meant to enable conservation managers to follow a logical decision-making process and this is part of conservation management. However, developing the required management plan for the individual site require extensive liaison with owners and sites users and often involves a management agreement (NCC, 1990).

English Nature (2006) presents a clear definition of what actions are required to manage and maintain geological sites. The details of how the site is used and its potential for education, details of management processes and frequency of monitoring required, the resources needed 
to deliver the management plan, and periodic review of management plan are key to the production of site management plan.

\subsection{Conservation Strategy of RIGS in Knowsley}

Conservation strategy for the sites is grouped into two and this is according to the similarities in the site type, features and condition. Therefore, the same development strategy can be applied to the two different groups. For group 1 (active stream section) includes: L1, L2, L3 and L6 and group 2 (inland exposures) includes: L4 and L5. The management strategies for both groups are shown in Table 1.

Table 1. Management Strategy for Sites L1, L2, L3 and L6 (Active stream section) and sites L4 and L5 (Inland exposures)

\begin{tabular}{|c|c|c|}
\hline Objective & Consideration and potential strategies & Management Proposals \\
\hline $\begin{array}{l}\text { 1. Monitoring must be } \\
\text { recognised as an integral } \\
\text { and essential component } \\
\text { of the planning system }\end{array}$ & $\begin{array}{l}\text { - Surveillance required in nature conservation } \\
\text { to ensure that formulated standards are } \\
\text { maintained. } \\
\text { - It is important to verify whether conservation } \\
\text { purposes are met } \\
\text { - Keeping track of changes to the sites overtime } \\
\text { and recording for data bank. }\end{array}$ & $\begin{array}{l}\text { - Constant monitoring of the } \\
\text { state of the sites should be } \\
\text { adopted by identified bodies or } \\
\text { authorities. } \\
\text { - Authorities should act } \\
\text { effectively to draw attention to } \\
\text { any need for enhancement and } \\
\text { to evaluate the effectiveness of } \\
\text { any conservation measures that } \\
\text { are needed to be carried out. } \\
\text { - Appropriate tracking of } \\
\text { changes to site over time and } \\
\text { records of changes, especially } \\
\text { using a graphic approach. }\end{array}$ \\
\hline $\begin{array}{l}\text { 2. Ensure a good practice } \\
\text { in recording all actions } \\
\text { undertaken in accordance } \\
\text { with a plan }\end{array}$ & $\begin{array}{l}\text { - An audit is essential for all the sites to make } \\
\text { data available to authorities, planners, } \\
\text { educational institutions and the public. } \\
\text { - Also important is the monitoring of activities } \\
\text { on the site in consonance with health and safety } \\
\text { risk associated with tipping and dumping. }\end{array}$ & $\begin{array}{l}\text { - Providing good practice } \\
\text { guidelines to anyone involved } \\
\text { or interested in the practice of } \\
\text { geological conservation. } \\
\text { - English Nature can help } \\
\text { enforce an act or task of } \\
\text { safeguarding and managing } \\
\text { these valuable features. } \\
\text { - Ensure effective conservation } \\
\text { legislation and policies and } \\
\text { sharing of good techniques in } \\
\text { terms of practical techniques. }\end{array}$ \\
\hline $\begin{array}{l}\text { 3. Ensure that certain } \\
\text { environmental factors } \\
\text { must be identified and } \\
\text { integrated in the planning }\end{array}$ & $\begin{array}{l}\text { - Plans to identify the objectives for all } \\
\text { conservation interest on the sites. } \\
\text { - Identifying features should be able to meet the } \\
\text { status required for conservation and be able to }\end{array}$ & $\begin{array}{l}\text { - Authorities should determine } \\
\text { whether the value of site could } \\
\text { contribute to Geodiversity. } \\
\text { - A criteria should be developed }\end{array}$ \\
\hline
\end{tabular}




\begin{tabular}{|c|c|c|}
\hline process & $\begin{array}{l}\text { influence the area. } \\
\text { - Measurable conservation objectives for each } \\
\text { interesting features }\end{array}$ & $\begin{array}{l}\text { to ensure a site has a potential to } \\
\text { represent the subject area. } \\
\text { - Items for positive management } \\
\text { in the planning system should } \\
\text { be identified: }\end{array}$ \\
\hline $\begin{array}{l}\text { 4. Ensure that plans and } \\
\text { management actions } \\
\text { should incorporate current } \\
\text { best practice and be open } \\
\text { to new and innovative } \\
\text { ideas }\end{array}$ & $\begin{array}{l}\text { - Regular update reporting is important to allow } \\
\text { development of new conservation techniques } \\
\text { required; both the new technical approach and } \\
\text { extensive consultation. } \\
\text { - The use of practical techniques and its } \\
\text { dissemination is essential. }\end{array}$ & $\begin{array}{l}\text { - Take action to employ new } \\
\text { developing } \quad \text { conservation } \\
\text { techniques e.g. formulating } \\
\text { possible methods to address } \\
\text { issues. }\end{array}$ \\
\hline $\begin{array}{l}\text { 5. Ensure the periodic } \\
\text { review of management } \\
\text { strategy within the time } \\
\text { scale that is appropriate to } \\
\text { the features }\end{array}$ & $\begin{array}{l}\text { - Objectives for all sites plans are an effective } \\
\text { re-examination of the vulnerable features. } \\
\text { - Obtaining and maintaining the required status } \\
\text { which will involve either an annual or long } \\
\text { term review to favour individual as the case } \\
\text { may be. }\end{array}$ & $\begin{array}{l}\text { - Coordinated body should be } \\
\text { set up to review management } \\
\text { plans. } \\
\text { - The period of review should } \\
\text { not be more than } 5 \text { years to } \\
\text { avoid danger of extinction. } \\
\text { - It is advisable to make } \\
\text { necessary amendments to site } \\
\text { recording or monitoring forms } \\
\text { subsequently. }\end{array}$ \\
\hline $\begin{array}{l}6 . \text { Internal management } \\
\text { reviews should be } \\
\text { supplemented with } \\
\text { reviews at predetermined } \\
\text { agreed dates }\end{array}$ & $\begin{array}{l}\text { - In some cases, it may be appropriate to hold } \\
\text { internal reviews; this can be considered to be } \\
\text { able to maintain the aims and options defined in } \\
\text { the plan for effective continuity in achieving } \\
\text { desired goals. }\end{array}$ & $\begin{array}{l}\text { - Decision makers can help } \\
\text { internally to develop, review } \\
\text { and amend plans and this could } \\
\text { be done yearly. }\end{array}$ \\
\hline $\begin{array}{l}\text { 7. Increase community } \\
\text { awareness on the value of } \\
\text { the site }\end{array}$ & $\begin{array}{l}\text { - Very limited or lack of site information boards } \\
\text { is presently available on the sites. } \\
\text { - A simple and concise site } \\
\text { information/interpretation boards that includes } \\
\text { a conservation element are likely to be } \\
\text { particularly effective in informing the members } \\
\text { of the public who visit the scenic areas. } \\
\text { - Sites that are under local management should } \\
\text { allow local people gain consultation on the site } \\
\text { management to share a sense of ownership. }\end{array}$ & $\begin{array}{l}\text { - The need to increase } \\
\text { awareness to enable interested } \\
\text { parties to make contributions. } \\
\text { - Utilising the national and local } \\
\text { media e.g. magazine } \\
\text { - Provision of information } \\
\text { boards and field centres, } \\
\text { particularly in areas that has } \\
\text { recreational features. } \\
\text { - Including earth science } \\
\text { conservation in and adult } \\
\text { education in the school } \\
\text { curricula. }\end{array}$ \\
\hline $\begin{array}{l}\text { 8. Ensure appropriate } \\
\text { accessibility and visibility }\end{array}$ & $\begin{array}{l}\text { - Accessibility is essential for all sites. A few of } \\
\text { the sites are on private properties and gaining } \\
\text { access was difficult. }\end{array}$ & $\begin{array}{l}\text { - Removal of vegetation } \\
\text { covering the geological features } \\
\text { where appropriate. }\end{array}$ \\
\hline
\end{tabular}




\begin{tabular}{|c|c|c|}
\hline & $\begin{array}{l}\text { - Site visibility is also a crucial factor in order } \\
\text { to have a clear view of the rock exposure, most } \\
\text { of the sites are affected by poor visibility due to } \\
\text { vegetation encroachment, and therefore rock } \\
\text { exposures were not visible enough for study. }\end{array}$ & $\begin{array}{l}\text { - Lichens, algae and mosses } \\
\text { should be cleared in } \\
\text { representative areas to give } \\
\text { clear picture of rock surfaces, } \\
\text { structures and features. } \\
\text { - Volunteers should be } \\
\text { encouraged to help in site } \\
\text { clearing. } \\
\text { - All sites should be open to the } \\
\text { public to appreciate and } \\
\text { contribute to its development. }\end{array}$ \\
\hline $\begin{array}{l}\text { 9. Prevent further } \\
\text { deterioration of the } \\
\text { geological features }\end{array}$ & $\begin{array}{l}\text { - Regular site checks and assessment will help } \\
\text { in obtaining a better picture of the condition of } \\
\text { the features. } \\
\text { - Despite poor exposures on all the sites, rapid } \\
\text { management is required to perform regular } \\
\text { monitoring of the sites. }\end{array}$ & $\begin{array}{l}\text { - Common to all the sites which } \\
\text { could be classified as 'Integrity } \\
\text { Site', an integrated approach is } \\
\text { essential to avoid threats from } \\
\text { vegetation encroachment which } \\
\text { is common to all the sites. }\end{array}$ \\
\hline $\begin{array}{l}10 . \quad \text { Improve the } \\
\text { recognition of the site for } \\
\text { educational and research } \\
\text { purposes }\end{array}$ & $\begin{array}{l}\text { - All sites are good areas for research due to the } \\
\text { interesting geological features present. } \\
\text { - Use of the site continuously for educational } \\
\text { and research purposes will help in securing its } \\
\text { recognition as important site for Geodiversity. }\end{array}$ & $\begin{array}{l}\text { - Authority should share link } \\
\text { with educational institutions. }\end{array}$ \\
\hline
\end{tabular}

\section{Conclusion}

The results show the summary of the audit, value and condition assessment of the RIGSs in the Knowsley area and also the images illustrating the present condition and the level of management practices in the study area. In general, the geological and geomorphological resources within the study area are greatly susceptible to various threats and require adequate management or action plan for protection from all forms of threats. For example, all the sites are under high threat of weathering, erosion, vegetation encroachment, littering and dumping of waste indiscriminately on the site, negligence and in some areas inaccessibility due to private ownership.

The proposed action plans will provide an enduring framework to assist in the planning, conservation, sustainable management and educational purposes for the geological sites. The Planning and Policy Statement 9 (PPS9) Biodiversity and Geological Conservation have made an impact within the planning system to promote the importance of Geodiversity in England and Wales (ODPM, 2005). Five out of the six RIGSs are important non-statutory sites which have been designated through the planning process in agreement with the DEFRA Local Sites Guidance in 1990 by the Nature Conservancy Council. The sixth site (Charlotte Pagsy) is not designated as a SLGI yet but possesses some geological features which might be considered for designation in future. However, the RIGSs Group of Merseyside in which 
Knowsley falls has been chosen based on the site selection standard of RIGSs according to Hertfordshire RIGSs Group.

A management plan has been proposed as a mechanism for the recognition, promotion, conservation and management of Geodiversity in Knowsley. The management plan described in this research work is to ensure that the sites which are in poor or deteriorating condition can be identified, managed and protected.

\section{References}

Adams, W. M., \& Hutton, J. (2007). People, parks and poverty: Political ecology and biodiversity conservation. Conservation and Society, 5(2), 147-183.

Alexander, M. (2008). Management planning for nature conservation. A theoretical basis \& practical guide. Netherlands: Springer Science. https://doi.org/10.1007/978-1-4020-6581-1

Brazier, V., Bruneau, P. M. C. Gordon, J. E., \& Rennie, A. F. (2012). Making space for nature in a changing climate: The role of geomorphology and soils in biodiversity conservation. Scottish Geographical Journal, 128(6), 211-233.

https://doi.org/10.1080/14702541.2012.737015

Burek, C. V., \& Prosser, C. D. (2008, April). History of geoconservation. The Geological Society of London, Special Publication, 200(4), 12-28.

Ellis, N. (2011 December). The geological conservation review (GCR) in Great Britain Rationale and methods. Proceedings of the Geologists' Association, 122(3), 353-362.

Google Maps. (2012 January 21). Lancaster map showing Knowsley [digital image]. Retrieved from http://www.itraveluk.co.uk/maps/england/1166/ lancashire/knowsley.html

Gordon, D. M. (2011): The fusion of ecology and behavioural ecology. Behavioural Ecology, 22(2), 225-230. https://doi.org/10.1093/beheco/arq172

Gray, M. (2008): Geodiversity: The origin and evolution of a paradigm: In the History of Geoconservation. Geological Society of London, Special Publication, 300(8), 31-36. https://doi.org/10.1144/SP300.4

Gray, M. (2013): Geodiversity. Valuing and conserving abiotic nature. New York: Wiley.

Gray, M., Gordon, J. E., \& Brown, E. J. (2013). Geodiversity and the Ecosystem Approach: The Contribution of Geoscience in delivering integrated environmental management. Proceedings of the Geologists' Association, 124(4), 659-673.

https://doi.org/10.1016/j.pgeola.2013.01.003

Hooke, J. M., \& Smith, M. J. (2012). The physical landscape of Britain and Northern Ireland: A project to increase geomorphological awareness. Scottish Geographical Journal, 128, 298-303. https://doi.org/10.1080/14702541.2012.725856

Miles, E. (2013). Involving local communities and volunteers in geoconservation across Herefordshire and Worcestershire, UK - The community earth heritage champions' project. 


\section{Macrothink}

Proceedings of the Geologists' Association, 124(4), 691-698.

https://doi.org/10.1016/j.pgeola.2012.11.003

Natural England. (2008). State of the natural environment 2008. Sheffield: Natural England. Retrieved from URL: http://publications.naturalengland.org.uk/publication/31043.

Brown, E. J., Prosser, C. D., \& Stevenson, N. M. (2012): Geodiversity, conservation and climate change: Key principles for adaptation. Scottish Geographical Journal, 128(3-4), 234-239. https://doi.org/10.1080/14702541.2012.725859

Stewart, I. S., \& Nield, T. (2013). Earth stories: Context and narrative in the communication of popular geoscience. Proceedings of the Geologists' Association, 124(4), 699-712. https://doi.org/10.1016/j.pgeola.2012.08.008

Tavares, A. O., Henriques, M. H., Domingos, A., \& Bala, A. (2015): Community involvement in geoconservation: A conceptual approach based on the geoheritage of South Angola. Sustainability, 7, 4893-4918. https://doi.org/10.3390/su7054893

Walmsley, C. A. (2010). Conserving geodiversity sites in a changing climate: Management challenges and responses. Geoheritage, 2, 123-136.

https://doi.org/10.1007/s12371-010-0016-7

Webber, M., Christie, M., \& Glasser, N. (2006). The Social and Economic Value of the UK's Geodiversity. English Nature Research Reports, 709(10), 1-144.

Whiteley, M. J., \& Browne, M. A.,E. (2013). Local geoconservation groups - Past achievements and future challenges. Proceedings of the Geologists' Association, 124(4), 674-680. https://doi.org/10.1016/j.pgeola.2012.07.004

Wilcox, C., Hardesty, B. D., Sharples, R. Griffin, D. A., Lawson, T. J., \& Gunn, R. (2013). Ghostnet impacts on globally threatened turtles: A spatial risk analysis for Northern Australia. Conservation, 6(4), 247-254. https://doi.org/10.1111/conl.12001

Worton, G. J., \& Gillard, R. (2013). Local communities and young people - The future of geoconservation. Proceedings of the Geologists'Association, 124(4), 681-690.

https://doi.org/10.1016/j.pgeola.2013.01.006

\section{Privacy Statement}

The names and E-mail addresses entered in this journal's site will be used exclusively for the purposes of this journal and will not be made available for any other purpose or to any other party.

\section{Copyright Disclaimer}

Copyright for this article is retained by the author(s), with first publication rights granted to the journal.

This is an open-access article distributed under the terms and conditions of the Creative Commons Attribution license (http://creativecommons.org/licenses/by/3.0/). 